\title{
CHARACTERIZATION OF THE SACCHAROMYCES CEREVISIAE Y500-4L KILLER TOXIN
}

\author{
Giselle A. M. Soares*; Hélia H. Sato \\ Departamento de Ciência de Alimentos, Faculdade de Engenharia de Alimentos, \\ Universidade Estadual de Campinas, Campinas, SP, Brasil
}

Submitted: March 17, 2000; Returned to authors for corrections: April 25, 2000; Approved: November 07, 2000

\begin{abstract}
The strain Saccharomyces cerevisiae Y500-4L, selected from the must of alcohol producing plants, liberates a toxin which is lethal to the commercial yeast produced by Fleischmann Royal Nabisco and other strains of yeast. This toxin was characterized, and the maximum production was obtained after 24 hours of incubation at $25^{\circ} \mathrm{C}$ in YEPD medium. The maximum activity was achieved between $\mathrm{pH} 4.1$ and 4.5 and between 22 and $25^{\circ} \mathrm{C}$ and maximum stability in the $\mathrm{pH}$ range 3.8 to 4.5 at $-10^{\circ} \mathrm{C}$. The killer toxin was inactivated by heating at $40^{\circ} \mathrm{C}$ for 1 hour at $\mathrm{pH} 4.1$. After concentration by ultrafiltration of culture supernatants and purification by gel filtration chromatography, the molecular weight of the purified toxin was estimated by SDS-PAGE to be about 18-20 kDa.
\end{abstract}

Key words: killer toxin, Saccharomyces cerevisiae, killer yeast

\section{INTRODUCTION}

Some yeast strains of Saccharomyces and other genera secrete into the medium protein compounds also known as killer toxins, which kill sensitive yeasts (1). The capacity to produce killer toxin can confer an advantage over more sensitive competitive strains growing in a fermentative process. Investigations revealed that the occurrence of the killer phenotype in yeast is widespread in alcohol fermentations for beverage production such as in breweries (10), saké (6), wine $(3,12,14,22,23)$ and tequila (8) plants, and more recently in sugarcane producing plants (18).

The killer toxins described are active against a variety of different yeasts often outside the genus and species of the producing strains. However interactions between killer yeasts and pathogenic fungi have also been described, indicating that such killer yeast toxins may have potential as novel antimycotic biocontrol agents for plant fungal pathogens and for treatment of human and animal fungal infections (26).

Killer yeasts and their toxins have found several applications. For example, they have been used as model systems in fundamental research for studying the mechanisms of regulation of eukaryotic polypeptide processing, secretion and receptor binding (5). Killer plasmids of $S$. cerevisiae, which code for killer toxin, have been used as cloning vectors in recombinant DNA technology for the expression of foreign protein. The mouse a-amylase was effectively secreted via the killer toxin signal $(24,25)$.

Studies on the nature of the killer factor produced by Saccharomyces have shown that this protein has a highly specific action spectrum and is dependent on specific $\mathrm{pH}$, temperature and aeration conditions (27). The activity of the toxin is only highly stable in a narrow $\mathrm{pH}$ range (4.2-4.7) (13, 16). The stability of the killer toxin decreases with elevation of temperature and is unstable at $\mathrm{pH}$ values above 5.0 (19).

There are various distinct killer toxins (29), but the structure and function of only a few have been studied at a molecular level, the K1 killer toxin of $S$. cerevisiae being the best characterized (2). Amino acid composition data for the purified yeast K1 S. cerevisiae T158c/S14a killer toxin showed that it is a heterodimeric protein containing a disulfide bond intersubunit with a similar molecular mass, both being about $11 \mathrm{kDa}$, resulting in a mature ab dimer with $20.658 \mathrm{kDa}$ (30). The molecular weight of the killer toxins differs depending on the strains. The molecular weight of the killer toxin of S. cerevisiae strain 28 (KT28) was estimated as 16

\footnotetext{
* Corresponding author. Mailing address: Departamento de Ciência de Alimentos, Faculdade de Engenharia de Alimentos, Universidade Estadual de Campinas - UNICAMP, CP 6121, CEP 13081-970, Campinas, SP, Brasil. Fax (+5519) 3289 2832. E-mail: gisoares@ hotmail.com
} 
$\mathrm{kDa}(15)$. Killer toxins from other yeast genera have molecular weights ranging between 18 and $300 \mathrm{kDa}$. The Kluyveromyces lactis killer toxin was described as a protein dissociated into two subunits with molecular masses of $27 \mathrm{kDa}$ and above 80 kDa (21). The strain Candida SW-55 has two toxins, each purified toxin giving a marked band with molecular mass of $36 \mathrm{kDa}$ in SDS polyacrylamide gel electrophoresis (28). The molecular weight of the Hanseniaspora uvarum killer toxin was estimated as $18 \mathrm{kDa}(17)$ and that of Hansenula anomala as $300 \mathrm{kDa}(7)$.

The strain S. cerevisiae Y500-4L, previously selected from the must of alcohol producing plants, showed a high fermentative capacity (11) and considerable killer activity against the Fleischmann and Itaiquara commercial brands of yeast and also against the standard killer yeasts $\mathrm{K}_{2}$ (S. diastaticus NCYC 713), $\mathrm{K}_{4}$ (Candida glabrata NCYC 388) and $\mathrm{K}_{11}$ (Torulopsis glabrata ATCC 15126). However $S$. cerevisiae Y500-4L showed sensitivity to the killer toxin produced by the standard killer yeasts $\mathrm{K}_{8}$ (Hansenula anomala NCYC 435) $\mathrm{K}_{9}$ (Hansenula mrakii NCYC 500), $\mathrm{K}_{10}$ (Kluyveromyces drosophilarum NCYC 575) and $\mathrm{K}_{11}$ (Torulopsis glabrata ATCC 15126) (20). The purpose of this investigation was to characterize the $S$. cerevisiae Y500-4L killer toxin.

\section{MATERIALS AND METHODS}

Yeast strain. The strain Saccharomyces cerevisiae Y5004L (11) was used as killer yeast. The commercial brand of yeast produced by Fleischmann Royal Nabisco was used as the sensitive strain.

Culture media. YEPD broth $(1.0 \%$ yeast extract, $2.0 \%$ peptone, $2.0 \%$ glucose, $0.1 \mathrm{M}$ citrate-phosphate buffer $\mathrm{pH} 5.0$ ) was used for killer toxin production. YEPD-MB agar (YEPD containing $0.01 \%$ methylene blue and $2.0 \%$ agar) was used for killer phenotype determination.

Growth conditions for killer toxin production. The killer strain S. cerevisiae Y500-4L was grown in flasks containing YEPD broth at $25^{\circ} \mathrm{C}$. Dry mass (cellular growth), $\mathrm{pH}$ and killer toxin production were analyzed in triplicates of the medium. Killer activity was determined based on the well test method, where aliquots of $200 \mathrm{ml}$ of the supernatant were added to small cylinders (10 $\mathrm{mm}$ X $8 \mathrm{~mm}$ external diameter) and applied to the YEPD-MB agar, previously sprayed with the sensitive yeast suspension. The plates were incubated at $25^{\circ} \mathrm{C}$ during $48 \mathrm{~h}$. The killer toxin activity was expressed in arbitrary units (U) (17). Ten U corresponded to that amount of killer toxin that caused an inhibition zone of $10 \mathrm{~mm}$ (18 $\mathrm{mm}$ measured diameter of inhibition zone minus $8 \mathrm{~mm}$ diameter of the cylinder).

Killer toxin concentrate. After $24 \mathrm{~h}$ cultivation on YEPD broth at $25^{\circ} \mathrm{C}$, the yeast cells were removed by continuous centrifugation at $2800 \mathrm{x} \mathrm{g}, 4^{\circ} \mathrm{C}$. The killer toxin obtained from the supernatant was tested at $8^{\circ} \mathrm{C}$ with $50 \%$ polypropylene glycol $(1: 1 \mathrm{v} / \mathrm{v})$; ethanol $(2: 1 \mathrm{v} / \mathrm{v}) ;$ acetone $(2: 1 \mathrm{v} / \mathrm{v}) ; 80 \%$ $\left(\mathrm{NH}_{4}\right)_{2} \mathrm{SO}_{4}$ saturation and by ultrafiltration using Amicon YM10 membranes.

Effect of the pH and temperature on killer activity. Killer toxin concentrated 10 times and sterilized using $0.45 \mathrm{~mm}$ membranes was dissolved in $0.1 \mathrm{M}$ citrate-phosphate buffer at different $\mathrm{pH}$ values: $3.5,3.8,4.1,4.5,4.9,5.4$. Aliquots of $200 \mathrm{ml}$ of the samples were added to small cylinders and applied to the YEPD-MB agar, previously sprayed with the sensitive yeast suspension, at the same $\mathrm{pH}$ as the sample (4). Five plates of each $\mathrm{pH}$ were incubated at $8,16,22,25$ or $30^{\circ} \mathrm{C}$, for $48 \mathrm{~h}$.

Killer toxin stability. The $\mathrm{pH}$ stability of the killer toxin was performed using samples which had been concentrated and filter sterilized, and adjusted to different $\mathrm{pH}$ values: 2.0, 3.0, 3.5, $3.8,4.1,4.5,4.9,5.4,6.0,7.0$ or 8.0. The samples were incubated at $-10,8$ and $25^{\circ} \mathrm{C}$. After $24 \mathrm{~h}$, the filtrates were adjusted to $\mathrm{pH}$ 4.1 and assayed for killer activity.

The temperature stability of the killing activity was determined at $\mathrm{pH} 4.1$. The samples were incubated at 8, 25, 30 and $40^{\circ} \mathrm{C}$ and assayed from 30 minutes to $4 \mathrm{~h}$.

Purification. The killer toxin of $S$. cerevisiae Y500-4L was purified using a two step gel filtration on Sepharose 6B (Pharmacia), described by Zhu et al. (30). The sample was eluted from a column $(2.5 \times 35 \mathrm{~cm})$ equilibrated with $50 \mathrm{mM}$ sodium acetate buffer $\mathrm{pH} 4.7$ at $8^{\circ} \mathrm{C}$. Fractions $(3 \mathrm{ml})$ were collected at $0.2 \mathrm{ml} / \mathrm{min}$. Fractions containing the bulk of the $280 \mathrm{~nm}$ absorbing material and killer activity were pooled, and the molecular weight of the purified killer toxin was estimated.

Killer toxin molecular weight determination. The molecular weight of the killer protein was estimated by gel filtration chromatography on Sephadex G-100 and by sodium dodecyl sulfate polyacrylamide gel electrophoresis (SDSPAGE). The gel filtration column was equilibrated with $50 \mathrm{mM}$ Tris-HCl buffer $\mathrm{pH} 7.5$ containing 0.1M KCl. Blue Dextran 2000 and protein molecular weight markers SIGMA MW-GF 200 were used. The sample was eluted at $0.16 \mathrm{ml} / \mathrm{min}$. The purified toxin was identified by SDS-PAGE performed as described by Laemmli (9), on a $12 \%$ (w/v) acrylamide monomer, $120 \mathrm{~V}, 20$ $\mathrm{mA}, 2 \mathrm{~W}$ for $1 \mathrm{~h}$. Amounts of $57 \mathrm{mg}$ of killer toxin sample and SIGMA SDS6 standard proteins were used. Protein was stained with Coomassie Blue G250.

\section{RESULTS AND DISCUSSION}

Growth conditions for killer toxin production. Fig. 1 shows the relation between growth, $\mathrm{pH}$ and killer toxin production. Killer toxin activity was maximum (inhibition halo=5 U) after $24 \mathrm{~h}$ growth of killer strain $\mathrm{S}$. cerevisiae Y500-4L, which corresponds to the end of the rapid growth phase and the beginning of the stationary growth phase. A little decrease of $\mathrm{pH}$ medium from 5.0 to 4.7 during fermentation was observed. 
Killer toxin concentrate. The best method to obtain killer toxin from the supernatant was by ultrafiltration at $8^{\circ} \mathrm{C}$, which conferred more stability on the toxin molecule than the other methods tested. Fig. 2 illustrates the killer activity of $S$. cerevisiae Y500-4L killer toxin against the sensitive yeast strain. The killer toxin obtained with polypropylene glycol, $\left(\mathrm{NH}_{4}\right)_{2} \mathrm{SO}_{4}$ and ethanol precipitation showed high killer activity. However, after freezing and gel filtration, the fractions lost the killer activity, showing a higher molecular instability than concentration by ultrafiltration. When precipitated with acetone the toxin showed no killer activity.

Effect of pH and temperature on killer activity. The killer toxin of $S$. cerevisiae showed greatest activity between $\mathrm{pH} 4.1-4.5$ and $22-25^{\circ} \mathrm{C}$. Fig. 3 shows that the optimal activity of the $S$. cerevisiae killer toxin was obtained at $\mathrm{pH}$ 4.5 and $22^{\circ} \mathrm{C}$. At $25^{\circ} \mathrm{C}$, the best activity was at $\mathrm{pH} 4.1$. At $30^{\circ} \mathrm{C}$, the activity was low in agar medium, being high at $\mathrm{pH}$
3.5. At $16^{\circ} \mathrm{C}$, the killer toxin showed activity between $\mathrm{pH}$ 3.8-4.9. However at this temperature, the sensitive strain showed lower growth than at $22^{\circ} \mathrm{C}$ and $25^{\circ} \mathrm{C}$. At $8^{\circ} \mathrm{C}$ the sensitive strain did not grow enough and the test for killer activity could not be performed.

Killer toxin stability. Fig. 4 illustrates the $\mathrm{pH}$ effect on killer toxin stability. The toxin was more stable in a range from $\mathrm{pH} 3.8$ to 4.5 and retained $80 \%$ of its activity in the range from $\mathrm{pH} 2.0$ to 3.5 , after incubation for $24 \mathrm{~h}$ at $-10^{\circ} \mathrm{C}$. At $8^{\circ} \mathrm{C}$, the killer toxin retained $50-60 \%$ of its activity after incubation for $24 \mathrm{~h}$, in a pH range from 2.0 to 5.4 and at $25^{\circ} \mathrm{C}$, $35 \%$ of its activity in a pH range from 2.0 to 4.5 . In the $\mathrm{pH}$ range from 6.0 to 8.0 , the killer toxin was inactivated at $8^{\circ} \mathrm{C}$ and at $-10^{\circ} \mathrm{C}$; and was inactivated at $\mathrm{pH} 5.4$ after incubation for $24 \mathrm{~h}$ at $25^{\circ} \mathrm{C}$. Shimizu et al. (19) observed that killer toxins of eight killer strains, classified as belonging to the genus Saccharomyces, were inactivated at $\mathrm{pH}$ values above 5.0.

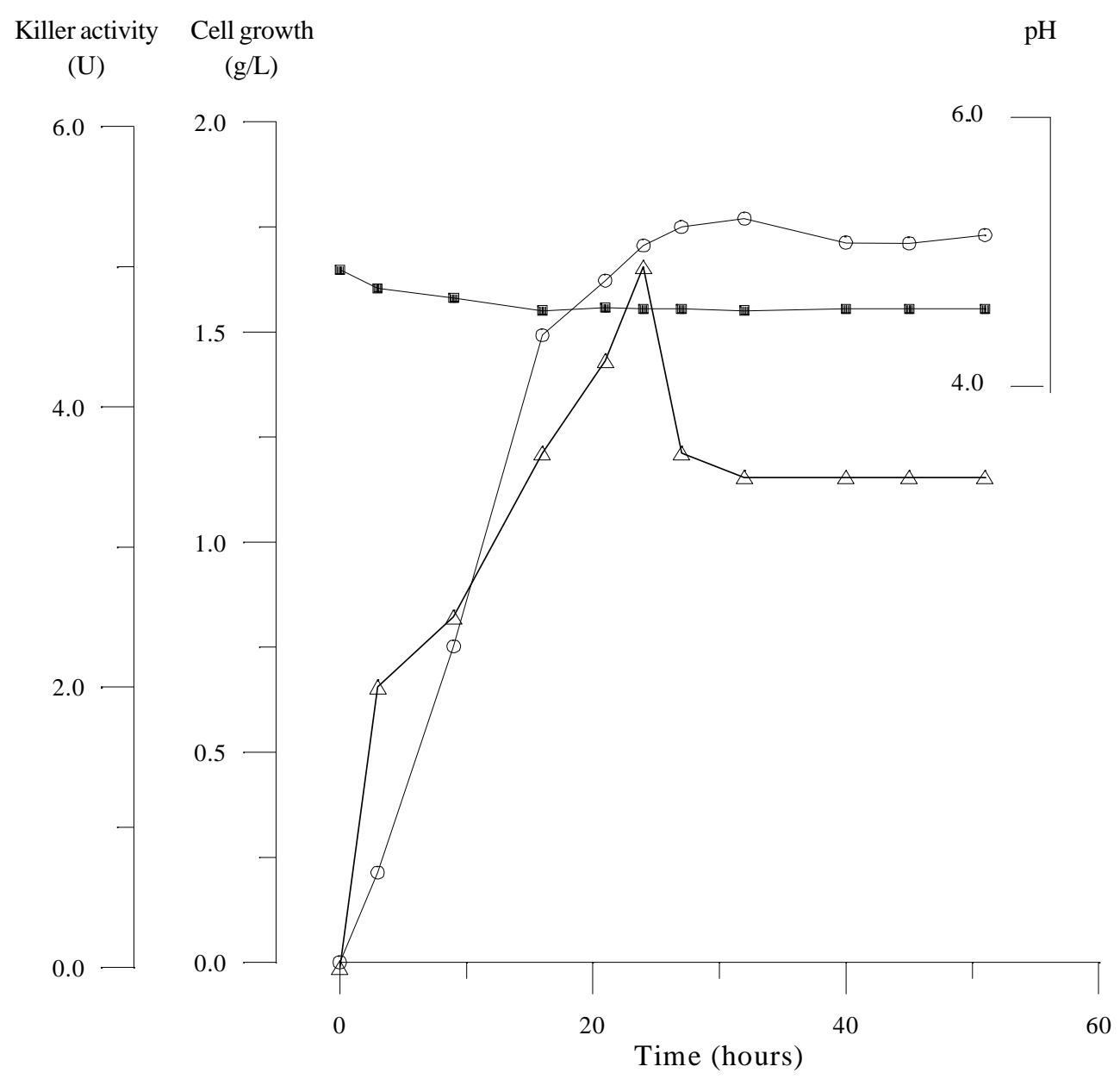

Figure 1. Growth of Saccharomyces cerevisiae Y500-4L and production of killer toxin. Cell growth $(\mathrm{O})$, toxin activity $(\Delta)$ and the $\mathrm{pH}$ of the broth (घ) were monitored. 


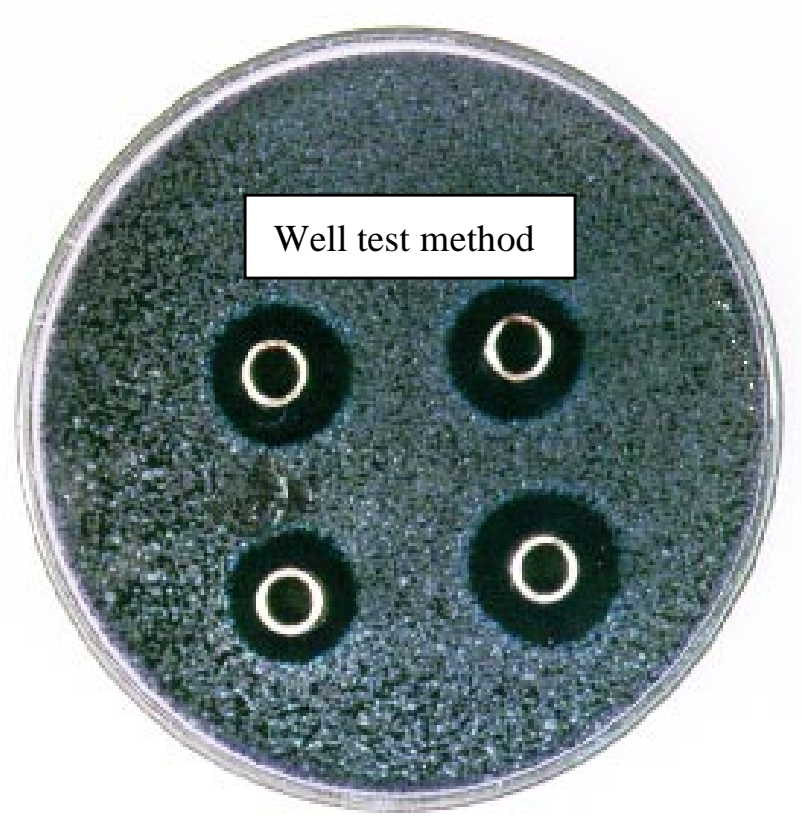

Figure 2. Inhibition zone caused by S. cerevisiae Y500-L killer toxin in YEPD-MB agar previously sprayed with a Fleischmann suspension.
Fig. 5 shows the effect of temperature on $S$. cerevisiae Y500-4L killer toxin stability. The toxin was stable after $4 \mathrm{~h}$ of incubation at $8^{\circ} \mathrm{C}$ and $25^{\circ} \mathrm{C}$ at $\mathrm{pH} 4.1$. At $30^{\circ} \mathrm{C}$, the toxin retained killer activity after $1 \mathrm{~h}$ of incubation; and lost $50 \%$ of this activity after $2 \mathrm{~h}$ and $30 \mathrm{~min}$. incubation. The killer toxin was completely inactivated by heating at $40^{\circ} \mathrm{C}$ for $1 \mathrm{~h}$ at $\mathrm{pH} 4.1$, showing instability like other Saccharomyces cerevisiae killer toxins, to temperatures above $38^{\circ} \mathrm{C}$, after the first hour of incubation $(19,27)$.

Purification and killer toxin molecular weight determination. Killer toxin of $S$. cerevisiae Y500-4L was purified 224 fold from the culture broth of yeast by ultrafiltration and using a two step gel filtration on a Sepharose $6 \mathrm{~B}$ column (Table 1). The molecular weight of the purified killer toxin protein was estimated by gel filtration chromatography on Sephadex G-100 and by sodium dodecyl sulfate polyacrylamide gel electrophoresis (SDS-PAGE). Fig. 6 shows the relation between $\mathrm{Ve} / \mathrm{Vo}$ and $\log \mathrm{MW}$ of the standard proteins and the killer toxin sample eluted on Sephadex G-100. The molecular weight of the purified toxin was estimated at $43 \mathrm{kDa}$ on gel filtration Sephadex G-100 and one single band was obtained with about 18 to $20 \mathrm{kDa}$ by SDS-PAGE, suggesting the possibility of the killer toxin from S. cerevisiae Y500-4L as being a dimeric molecule.

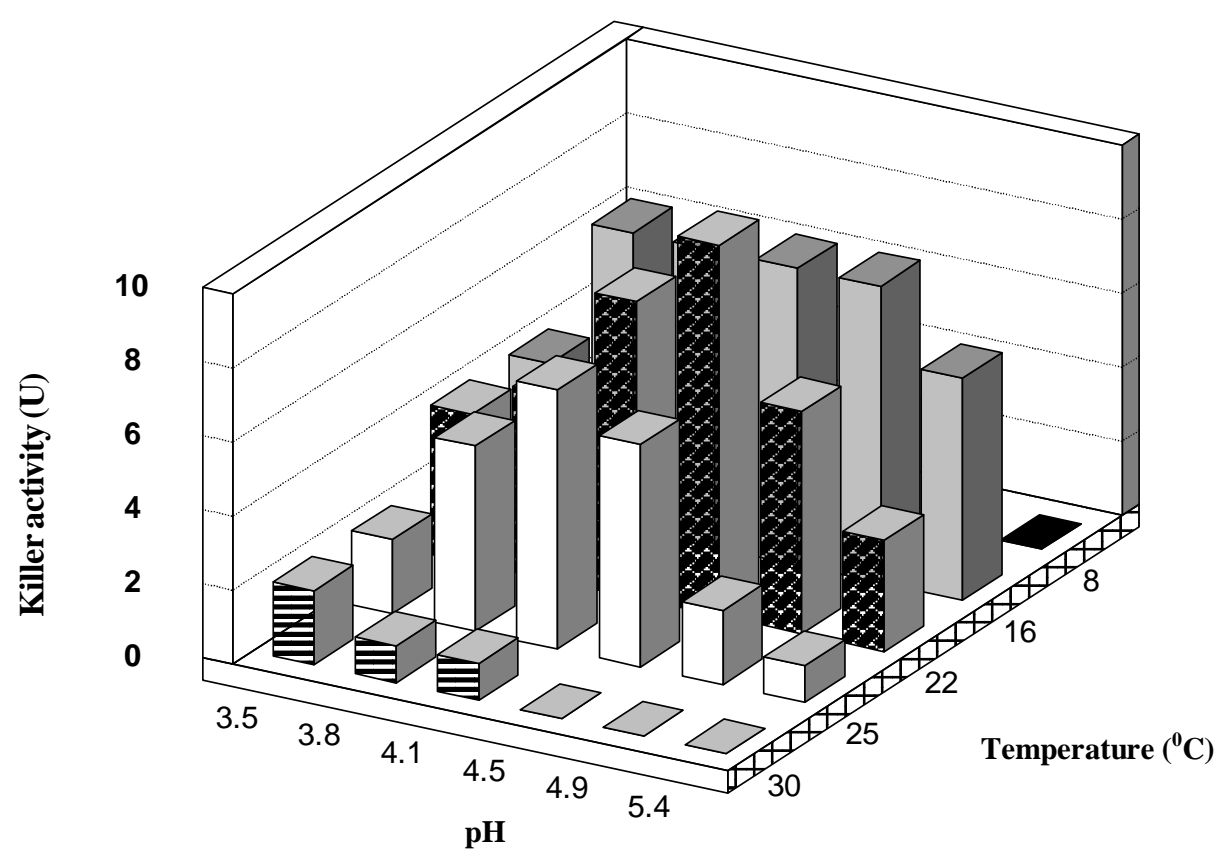

Figure 3. Effect of the $\mathrm{pH}$ and temperature on Saccharomyces cerevisiae Y500-4L killer toxin activity. 
Table 1 Purification of the killer toxin of Saccharomyces cerevisiae Y500-4L by ultrafiltration and gel filtration chromatography on Sepharose 6B.

\begin{tabular}{|c|c|c|c|c|c|c|}
\hline & $\begin{array}{l}\text { Volume } \\
(\mathrm{ml})\end{array}$ & $\begin{array}{l}\text { Protein } \\
(\mathrm{mg} / \mathrm{ml})\end{array}$ & $\begin{array}{l}\text { Activit } \\
\text { (U/ml) }\end{array}$ & $\begin{array}{l}\text { ller toxin } \\
\text { (U/mg) }\end{array}$ & Factor & $\begin{array}{l}\text { Yield } \\
(\%)\end{array}$ \\
\hline Cell free culture liquid & 660 & 11.15 & 6 & 0.54 & 1 & 100 \\
\hline Concentrated culture liquid & 36 & 16.81 & 16 & 0.95 & 1.7 & 15 \\
\hline Gel filtration column & 3 & 0.23 & 28 & 121 & 224 & 2 \\
\hline
\end{tabular}

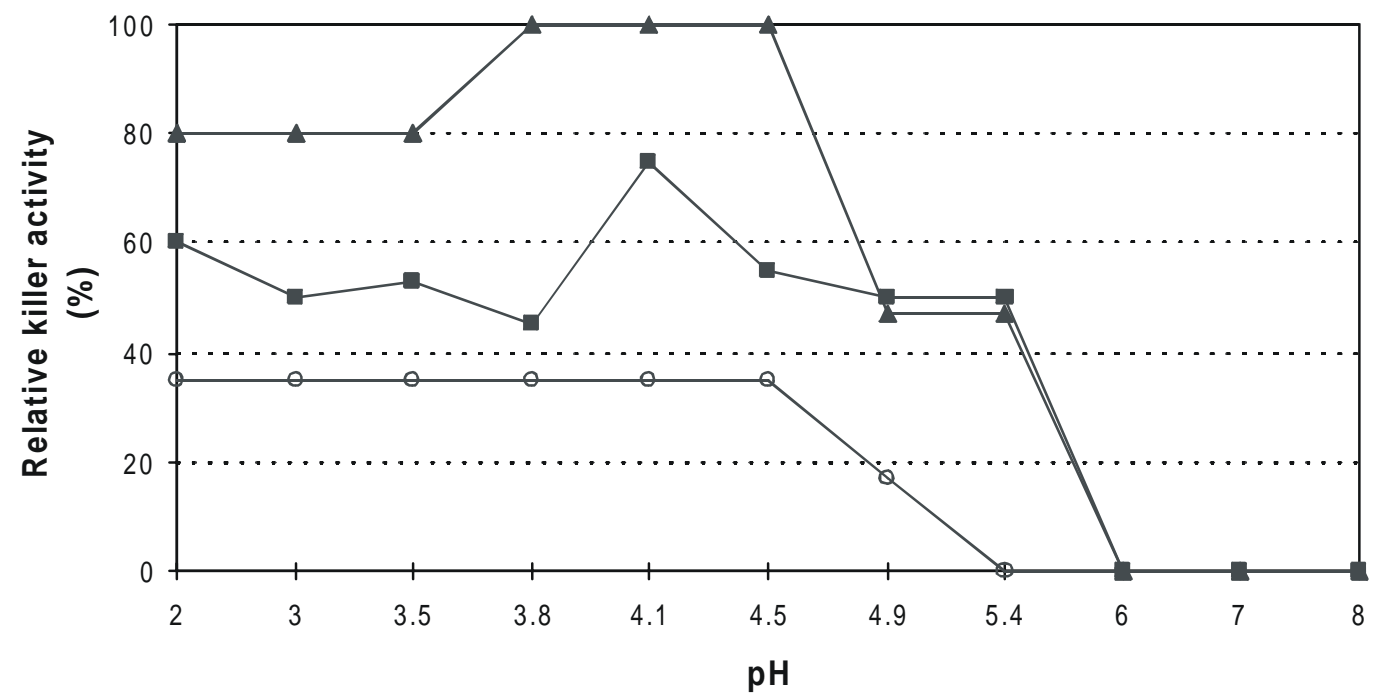

Figure 4. Stability of Saccharomyces cerevisiae Y500-4L killer toxin to $\mathrm{pH}$. Toxin activity at $25^{\circ} \mathrm{C}(\mathrm{O}) ; 8^{\circ} \mathrm{C}(\mathbf{\square})$ and $-10^{\circ} \mathrm{C}$

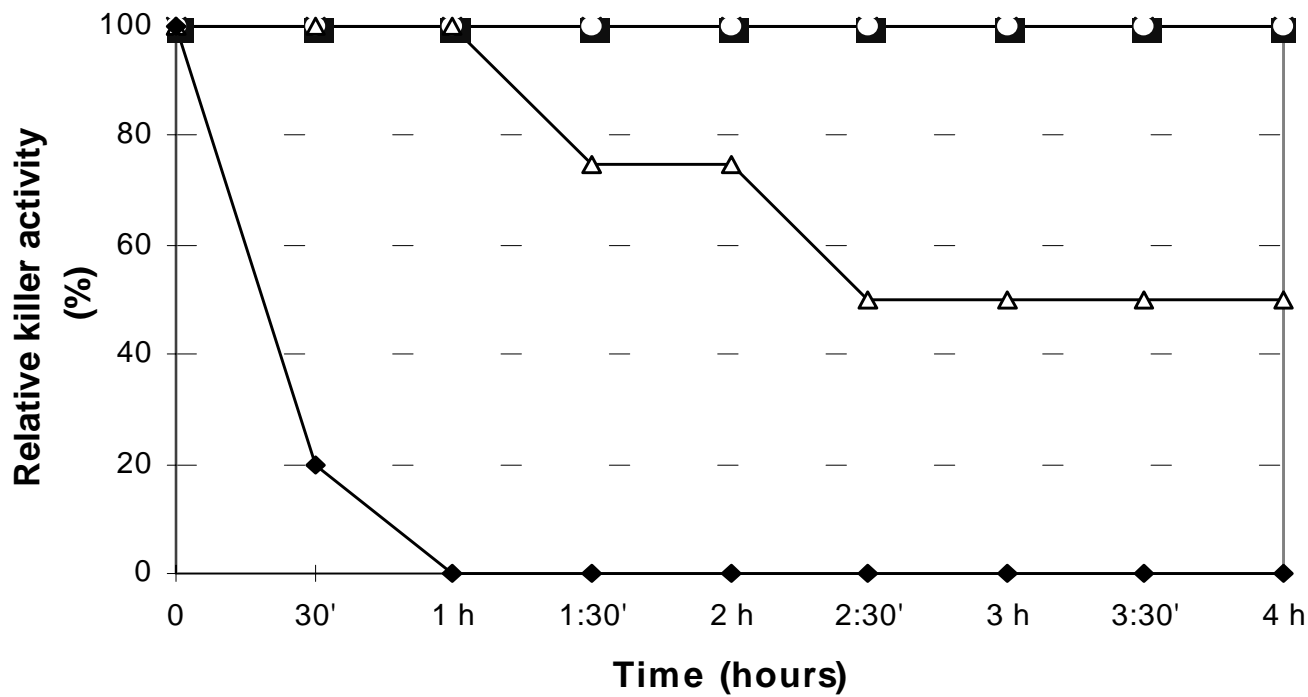

Figure 5. Stability of Saccharomyces cerevisiae Y500-4L killer toxin to temperature. Toxin activity at $8^{\circ} \mathrm{C}(\square) ; 25^{\circ} \mathrm{C}(\mathrm{O})$; $30^{\circ} \mathrm{C}(\Delta)$ and $40^{\circ} \mathrm{C}(\diamond)$. 


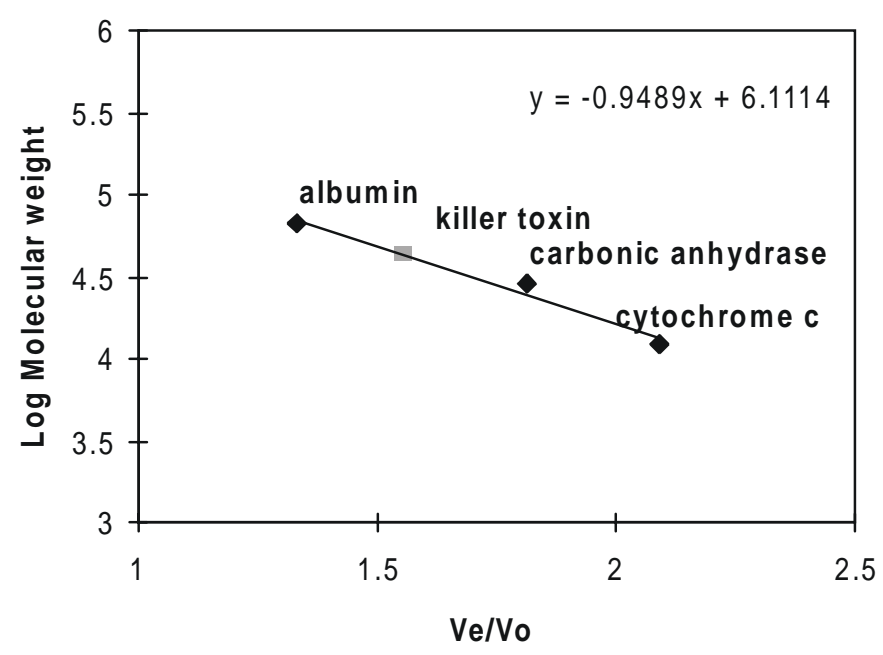

Figure 6. Calibration curve (u) for the determination of molecular weight of the killer toxin (n) of Saccharomyces cerevisiae Y500-4L on Sephadex G-100 column.

\section{ACKNOWLEDGMENTS}

The authors thank CNPq for the financial support.

\section{RESUMO}

\section{Caracterização da toxina "killer" da linhagem de Saccharomyces cerevisiae y500-41}

A linhagem de Saccharomyces cerevisiae Y500-4L, selecionada de mosto de fermentação de usina de álcool, produz toxina "killer", letal à levedura comercial Fleischmann Royal Nabisco e outras linhagens de leveduras. Esta proteína foi caracterizada, verificando-se que a produção máxima foi obtida após 24 horas de incubação a $25^{\circ} \mathrm{C}$ em meio YEPD. A toxina "killer" apresentou maior atividade na faixa de $\mathrm{pH}$ 4,14,5 e temperatura de $22-25^{\circ} \mathrm{C}$; e maior estabilidade na faixa de $\mathrm{pH} 3,8-4,5 \mathrm{a}-10^{\circ} \mathrm{C}$, sendo totalmente inativada após 1 hora de incubação a $40^{\circ} \mathrm{C}$ em pH 4,1. Após concentração a partir do sobrenadante do meio de cultura através de ultrafiltração e purificação por cromatografia de filtração em gel, estimouse, através de SDS-PAGE, que o peso molecular desta toxina é cerca de 18 a $20 \mathrm{kDa}$.

Palavras-chave: Toxina "killer", Saccharomyces cerevisiae, levedura "killer"

\section{REFERENCES}

1. Bendová, O. The killer phenomenon in yeasts. Folia microbiol., 31: 422433, 1986.
2. Brown, J.L; Roemer, T.; Lussier, A.M.S.; Bussey, H. The K1 killer toxin: molecular and genetic applications to secretion and cell surface assembly. In: Johnston, J.R. Molecular Genetics of Yeast- a practical approach. The practical approach series, 1994, p.217-265.

3. Carrau, F.M.; Neirotti, E.; Gioia, O. Stuck wine fermentations: effect of killer/ sensitive yeast interactions. J. Ferment. Bioeng., 76: 67-69, 1993.

4. Goto, K.; Morikawa, S.; Sato, H.H.; Park, Y.K. Characteristics of the killer yeast n.337 isolated from alcohol fermentation mash in Brazil. J. Brew. Soc. Japan, 85: 895-899, 1990.

5. Hampsey, M. A review of phenotypes in Saccharomyces cerevisiae. Yeast, 13: 1099-1133, 1997.

6. Imamura, T.; Kawamoto, M; Takaoka, Y.Characteristics of main mash infected by killer factor. J. Ferment. Technol., 52: 293-299, 1974

7. Kagiyama, S.; Aiba, T.; Kadowaki, K.; Mogi, K. New killer toxins of halophilic Hansenula anomala. Agric. Biol. Chem., 52: 1-7, 1988.

8. Lachance, M.A. Yeast communities in a natural tequila fermentation. Antonie Leeuwenhoek, 68: 151-160, 1995.

9. Laemmli, U.K. Cleavage of structural proteins during the assembly of the head of bacteriophage T4. Nature, 227: 680-685, 1970.

10. Maule, A.P.; Thomas, P.D. Strains of yeast lethal to brewery yeasts. J. Inst. Brew., 79: 137-141, 1973.

11. Nascimento, A.M. Isolamento e seleção de leveduras produtoras de fator killer para aplicação na produção de bebidas alcoólicas. Campinas, 1994. 74p. (Ms. Thesis. Fac. Eng. de Alimentos, Universidade Estadual de Campinas).

12. Naumov, G.I., Tyurina, L.V., Buryan, N.I., Naumova, T.I. Winemaking, an ecological niche of type K2 killer Saccharomyces. Bio. Nauki, 16: 103-107, 1973.

13. Palfree, G.E.; Bussey, H. Yeast Killer Toxin: purification and characterization of the protein toxin from Saccharomyces cerevisiae. Eur. J. Biochem., 93: 487-493, 1979.

14. Petering, J.E.; Symons, M.R.; Langridge, P.; Henschke, P.A. Determination of killer yeast activity in fermenting grape juice by using a marked Saccharomyces wine yeast strain. Appl. Environ. Microbiol., 57: 32323236, 1991.

15. Pfeiffer, P.; Radler, F. Purification and characterization of extracellular and intracellular killer toxin of Saccharomyces cerevisiae strain 28. J. Gen. Microbiol., 128: 2699-2706, 1982.

16. Pfeiffer, P.; Radler, F. Comparison of the killer toxin of several yeasts and the purification of a type K2. Arch. Microbiol., 137: 357-361, 1984.

17. Radler, F.; Schmitt, M.J.; Meyer, B. Killer toxin of Hanseniaspora uvarum. Arch. Microbiol., 154: 175-178, 1990.

18. Sato, H.H.; Pastore, G.M.; Park, Y.K. Study of some characteristics of newly isolated killer yeast. Rev. Microbiol., 24: 71-72, 1993.

19. Shimizu, K.; Adachi, T.; Kitano, K.; Takayuki, S.; Totsuka, A.; Hara S.; Dittrich, H.H. Killer properties of wine yeasts and characterization of killer wine yeasts. J. Ferment. Technol., 63: 421-429, 1985.

20. Soares, G.A.M.; Sato, H.H. Killer toxin of Saccharomyces cerevisiae Y500-4L active against Fleischmann and Itaiquara commercial brands of yeast. Rev. Microbiol., 30: 253-257, 1999.

21. Sugisaki, Y.; Gunge, N.; Sakaguchi, K.; Yamasaki, M.; Tamura, G. Characterization of a novel killer toxin encoded by a double-stranded linear DNA plasmid of Kluyveromyces lactis. Eur. J. Biochem., 141: 241-245, 1984

22. Sulo, P.; Michalcáková, S. The K3 type killer strain of genus Saccharomyces for wine production. Folia Microbiol., 37: 289-294, 1992.

23. Thornton, R.J. Genetic characterization of New Zealand and Australian wine yeasts. Antonie Leeuwenhoek, 52: 97-103, 1986.

24. Tokunaga, M.; Wada, N.; Hishinuma, F. A novel yeast secretion vector utilizing secretion signal of killer toxin encoded on the yeast linear DNA plasmid pGKL1. Biochem. Res. Commun., 144: 613-619, 1987.

25. Tokunaga, M.; Kawamura, A.; Omori, A.; Hishinuma, F. Purification and determination of $\mathrm{NH}_{2}$-terminal amino acid sequence of mouse a-amilase secreted from Saccharomyces cerevisiae: correct processing of the secretion signal from pGKL1 killer $28 \mathrm{kDa}$ precursor protein. Biochim. Biophys. Acta, 1080: 135-137, 1991.

26. Walker, G.M.; McLeod, A.H.; Hodyson, V.J. Interactions between killer yeasts and pathogenic fungi. FEMS Microbiol. Lett., 127: 213-222, 1995.

27. Woods, D.R.; Bevan, E.A. Studies on the nature of the killer factor produced by Saccharomyces cerevisiae. J. Gen. Microbiol., 51: 115-126, 1968. 
28. Yokomori, Y.; Akiyama, H.; Schimizu, K. Toxins of a wild Candida killer yeast with a novel killer property. Agric. Biol.Chem., 52: 2797-2801, 1988.

29. Young, T.; Yagiu, M. A comparison of the killer character in different yeasts and its classification. Antonie Leeuwenhoek, 44: 59-77, 1978.
30. Zhu, H.; Bussey, H.; Thomas, D.I.; Gagnon, J.; Bell, W. Determination of the carboxyl termini of the a e b subunits of yeast K1 Killer toxin. J. Biol. Chem., 262: 10728-10732, 1987. 